\title{
Competitive relations and communication in team sports
}

\author{
Ioana Curitianu ${ }^{1}$, Elena Balint ${ }^{2}$ \\ ${ }^{1}$ Assistant PhD, Transilvania University of Brasov, Faculty of Physical Education and Mountain Sports, \\ Department of Physical Education and Special Motility, No.1 Colina Universităţii Street, Brasov, 500068, \\ Romania, Phone number - 0740455088 \\ ioana.curitianu@gmail.com \\ ${ }^{2}$ Professor, Transilvania University of Brasov, Faculty of Physical Education and Mountain Sports, Department \\ of Physical Education and Special Motility, No.1 Colina Universităţii Street, Brasov, 500068, Romania, Phone \\ number - 0746656113 \\ liabalint@gmail.com
}

\section{ABSTRACT}

The sporting environment is a rich, unique, and salient context in which to study the basic and applied nature of a variety of social dynamics. Issues such as leadership, collective efficacy, team cohesion, and group goal setting undoubtedly have great theoretical and practical value within sport teams.

Sport is completely permeated by the question of the diversity which it vividly enacts. The same way sports blends sporting spirit, competition drive and fair play it should also blend culturally different envisaged notions of non-uniformity, diversity, enrichment through other culture, other skin color, other language and other style of living.

All disciplines are concerned to a more or less intense degree, depending on their popular support or lack of it and on the culture which they convey. Multiple origins and complex careers are now a hallmark: handball, rugby, basketball as well as individual sports like athletics, judo and tennis have their champions stemming from diversity, who form the tip of an equally variegated iceberg of school and amateur sport (Diamond P., Hausman J., 1994).

\section{Indexing terms/Keywords}

Competitive relations, communication team sports

\section{Academic Discipline And Sub-Disciplines}

Sport sciences

\section{SUBJECT CLASSIFICATION}

Sport science

\section{TYPE (METHOD/APPROACH)}

\section{Review article}

\section{Council for Innovative Research}

\section{Peer Review Research Publishing System}

Journal: Journal of Social Sciences Research

Vol .7, No.2

jssreditor.cir@gmail.com

www.jssronline.com 


\section{INTRODUCTION}

The team is considered to be the psychosocial reality of the sport activity, of cohesion and her capacity depending both upon performance and satisfaction of the players.

The efficacy of the team depends on the quality of the relations between players and it's forming is based upon the need to achieve performance for players. Considering that sports have a collective effect in modern societies, different groups of people dealing with sports, interact socially with each other because of sports.

The role of sports is that it gives power to behave freely to the inner worlds of individuals. It causes individuals to rediscover themselves and display their skills and therefore plays an important role in socialization of individuals. Besides sports activities move the individuals away from the stress of modern life and provide opportunity for psychological and physical relief (Sahan, H., et. al., 2012).

The sport environment is rich and unique in which we can study the basic and applied nature of a variety of social dynamics. Issues such as leadership, collective efficacy, team cohesion, and group goal setting undoubtedly have great theoretical and practical value within sport teams. These issues all rely on one social process that may be the most important component of intra-team communication and colaboration.

In researches made by Yaman et. al., 2003, Yilmaz 2006 they stated that sports are very important for socialization. Brewer B.W., 2009, considers that athletes apply tactics and line of attacks more efficiently, bear distress, focus better, detect additional original solutions to sport circumstances, force themselves to perform better, discover new abilities rapidly or set up themselves to contest more advanced than their substantial comparable peers.

\subsection{Communication in team sports}

The study of communication within sports teams is appealing for a variety of reasons. Teams within sports are a social group that represents a prime area to study social issues that appear inside these groups. Unambiguous outcomes allow tests in regard to the effectiveness of communication styles and patterns.

The tendency of teammates to discuss responsibilities and expectations is related to both social and task cohesion and several studies have shown a correlation between team communication and cohesion (Sullivan P.A., 1995; Widmeyer W.N. et.al., 1991) and other aspects of team unity (Sullivan P.A., 1993).

Feltz D.L., Lirgg C.D., 1998, believe that communication between teammates should affect self and team confidence, as well as the efficacy and confidence of coaches in their players (Chase M.A. et. al., 1997).

Individual and team performance have been correlated with the style of communication within teams (DiBerardinis J.D. et.al., 1983; Williams J., Widmeyer W.N., 1991). Dale G.A. et. al., 1996, used a performance profiling technique to describe how athletes characterize a successful team and coach.

Emerson R.M., 1966, conducted a study upon team communication in sport and how communication tends to measure a social-task dichotomy in conversations or focuses exclusively on task-oriented discussions.

Recent articles also show the importance of task communication. Williams J. et. al., 1991, conducted a series of studies on team dynamics and defined intra-team communication as how often teammates gave each other tips about play during practices and tournaments. This study found communication to be effective being a significant predictor of performance and cohesion in team sports.

There have been other researchers that focused on describing the practical importance of interactions between players in a team, such as acceptance, valuing, understanding (Sullivan P.A., 1993), ability to listen to each other, tendency to trust, reaction to expressions of affection, and reaction to conflict (DiBerardiniset al., 1983; Sullivan P.A., 1995).

Sullivan P.A., 1995, in his study found that different social aspects of team communication were related to cohesion, while DiBerardinis et al., 1983, believe that improvements in communication skills are related to increased individual performance.

There is a rich history of social dynamics within sport psychology. Team cohesion and social support are two wellestablished team dynamics within sport that both emphasize a task and social distinction (Brawley L.R. et.al., 1998). Issues within sport psychology that may be considered resources include information about the way players react in a game, orientation, stimulation and evaluation (Hanin Y., 1992), acceptance and understanding (Sullivan P.A., 1993), reactions to expressions of anger or love (DiBerardinis J.D. et al., 1987), and emotional support and tangible support (Rosenfeld L.B., Richman J.M., 1997).

Effective team communication consists of the exchanges of acceptance, distinctiveness, positive and negative conflicts. These factors include both verbal and nonverbal indicators. Sullivan P.A., 1993, finds acceptance as a factor of genuineness and valuing. The factor of distinctiveness refers to communicating a unique but shared identity. This notion has been commented extensively in the literature on team building (Prappavessis H. et.al, 1997).

Research on conflicts that appear within sports teams is limited, but does support the notions of both positive conflict and negative conflict. Sullivan P.A. et. al., 2000 found that reactions to conflict were related negatively to cohesion and Copeland B.W., Wida K., (1996) commented on the negative role of such behaviors.

Variables such as player satisfaction, team effectiveness, team unity and player performance all have been linked previously to communication within teams. Inside a team, composed of different personalities that have a common goal, that of winning a game or an important competition, if there is no communication in resolving especially tactical problems, the results are low and unsatisfying.

\subsection{Competitive relations in team sports}

Team sports have a common goal depending of its realization, we can follow the development of competitive relationships, conflicts and homogenization, conditioned by external or internal reasons. Research findings have revealed that an over emphasis on winning and competitive outcomes may reduce pro-social conduct and even promote antisocial behavior (Orlick, 1990; Ommundsen Y. et. al., 2003; Kavussanu M., Roberts G.C., 2001). 
Studies upon sport groups provide accurate and efficient measurement of results obtained by a group, that can be quantified in the number of balls lost or won, repeated errors, unsolved tactical situations etc. (Loy J.V. et.al., 1979; Shaffer D.R., 2005; Spink K.S., 1992).

A comparison is often made between the goal in developing the ability in which effort and improvement become the criteria of success and the goal in demonstrating the ability or hide the demonstration of a lack of ability in which normative ability and besting others are perceived as prerequisites for personal success (Dweck C.S., Leggett E.L., 1988; Nicholls J.G., 1989).

Achieving goals is an important predictor of a host of achievement-relevant processes and outcomes (Harackiewicz J.M. et al., 1998; Ommundsen Y. et.al., 1999; Duda J., 2001; Biddle S.J.H., 2001). According to Nicholls J.G., 1989, winning becomes the main objective and players do anything to win, including deceptive tactics and un sports behavior. A taskorientated player tends to view the achievement activity as an end in itself and is concerned with self-referenced improvement and learning. For these individuals, exerting effort and following the rules and regulations of the activity should be the main emphasis (Duda J. et al., 1991).

Snajder G., 1984, conducted an analysis upon a top volleyball team before and after an important international tournament, where the team achieved a great result. Taxonomic structure of the team had changed considerably after the end of the tournament. A successful outcome on this tournament had a positive impact on the micro-structure in the team's next season, in terms of forming the sub-groups, related by functional criteria.

Simenc Z., 1985, analyzed the micro-structure of the players from 12 teams in first national water polo league which showed that the water polo teams are fairly homogeneous, as a whole. The homogeneity of the team significantly affected the score that the team obtained at home, while the quality and age of the first six players in the pool had a significant impact on the success of the team as a guest.

A few recent studies on the achievement goal theory have examined aspects about the purposes of sport and the causes of success in sport. Studies focusing on the effects of dispositional goals have generally shown that ego orientation is associated with the belief that the purpose of sport is to enhance social status and gain financial reward, while deception and taking an illegal advantage are believed to be the causes of sporting success (Roberts G.C., Ommundsen Y., 1996; Carpenter P., Yates B., 1997; White S.A. et.al., 1996).

Lucic Z., Viskic-Stalec N., 1994 used the sociometric method on a junior basketball team, confirming the thesis about the changing status of an individual within the group membership variations.

Marelic N. et. al., 2007 examined cadet volleyball teams at the European Championship, using the sociometric method. They showed that the teams are in general divided into two subgroups, with major roles of a team captain and best player of the team. Significant differences were found in measurements performed before and after the European Championship in the variables of functional type. The status of team captain proved to be different in the initial and final measurement.

Hotuleva M.S., 2009, showed that psycho technical exercising has the influence to improve the quality of group cohesion in basketball.

Rogulj N., et. al. 2006, considers that the success in handball depends on cooperation and communication of the players in the exercise group and in collective tactical actions. It is important that the handball team is emotionally and functionally balanced. In addition to the individual performance and creativity of individual players, or personality traits, the necessities are the actions with a prevalence of a discipline and social responsibility.

Bebetsos E. et. al., 2011, emphasizes the influence of a negative relationship between role ambiguity and role satisfaction inside a handball team, which can also affect the alignment of team actions. Several researchers investigated the interplay between dispositional goals and the motivational climate in the generation of achievement-related and sociomoral outcomes in sport (Newton M., Duda J., 1999; Duda J., 2001; Treasure D.C., 2001). In these aspects, the leadership of the coaches has a vital role, but also within teams, such the role of a team captain (Murray N.P., 2006; Serpa S., 1991).

Lorentzen S., 1994 considered the handball team as a group matrix, in which individuals are opened systems, so the guided group discussion and the conversation between team members may contribute to a better cohesion and function of a team.

Kavussanu M. et al., 2002, examined the role of the moral atmosphere and perceived motivational climate on young basketball players. They found that a performance climate predicted neither judgments favoring the appropriateness of injurious acts nor incidences of amoral behavior.

As an individual behavioral disposition, an achievement goal is conceptualized as the perceived or cognitive dynamic focus of task engagement. The type of goal adopted is presumed to establish the perceptual set for how individuals interpret and experience achievement settings. (Elliot A.J., 1997)

\section{Conclusions}

1. The study of communication in team sport is a valuable tool: a statistically and theoretically sound, multidimensional measurement of teammates, exchanges that can be considered effective communication. This instrument can help to illuminate further the practical and theoretical nature of team dynamics within sport.

2. Achievement goals, motivational climates and their interactions, are important precursors of communication and competitive relations among players involved in competitive team sports. Sports is a very important factor for socialization, especially active individuals in team sports can be more social.

3. The study of team communication will provide a substantial extension of what is known today about teams in sport.

4. Communication within a team has a special importance especially in a game, when it has a motric and gestural character with technical and tactical significations, oriented towards achieving the performantial aim, that of winning games and tournaments. 


\section{REFERENCES}

[1] Bebetsos, E., Theodorakis, N., Tsigilis, N. (2011). Relations between Role Ambiguity and Athletes' Satisfaction among Team Handball Players. The Sport Journal, 14. http://www.thesportjournal. org/article/relations-between-roleambiguity-and-athletesrsquo-satisfaction-among-team-handball-players

[2] Biddle, S.J.H. (2001). Enhancing motivation in physical education. In G.C. Roberts (Ed.), Advances in motivation in sport and exercise. Champaign, IL: Human Kinetics.

[3] Brewer, B. W. (2009). Handbook of sports medicine and science sport psychology, Wiley-Blackwell, USA.

[4] Carpenter, P., Yates, B. (1997). Relationship between achievement goals and the perceived purposes of soccer for semi-professional and amateur players. Journal of Sport and Exercise Psychology, 19, 302-312.

[5] Chase, M. A., Feltz, D. L., Lirgg, C.A. (1997). Do coaches' efficacy expectations for their teams predict team performance? The Sport Psychologist, 11, 8-23.

[6] Copeland, B. W., Wida, K. (1996). Resolving team conflict: Coaching strategies to prevent negative behavior. Journal of Physical Education, Recreation, \& Dance, 67(4), 52-54.

[7] Dale, G A., Wrisberg, C.A. (1996). The use of a performance profiling technique in a team setting: Getting athletes and coach on the "same page." The Sport Psychologist, 10,261-277.

[8] Diamond, P. and Hausman, J. (1994). Contingent valuation: Is some number better than no number? The Journal of economic perspectives, 8(4), pp. 45-64.

[9] DiBerardinis, J.D., Banvind, J., Flanningam, R.R., Jenkins, V. (1983). Enhanced interpersonal relation as predictor of athletic performance. International Journal of Sport Psychology, 14,243-251.

[10] Duda, J. (2001). Achievement goal research in sport: Pushing the boundaries and clarifying some misunderstandings. In G.C. Roberts (Ed.), Advances in motivation in sport and exercise. Champaign, IL: Human Kinetics.

[11] Duda, J.L., Olson, L.K., Templin, T.J. (1991). The relationship of task and ego orientation to sportsmanship attitudes and the perceived legitimacy of injurious acts. Research Quarterly for Exercise and Sport, 62, 79-87.

[12] Dweck, C.S., Leggett, E.L. (1988). A social cognitive approach to motivation and personality. Psychological Review, 95, 265-273

[13] Elliot, A.J. (1997). Integrating the 'Classic' and 'Contemporary' approaches to achievement motivation: A hierarchical model of approach and avoidance achievement motivation. In M.L.

[14] Emerson, R. M. (1966). Mount Everest: A case study of communication feedback and sustained group goal striving. Sociometry, 29, 2, 13-227.

[15] Feltz, D.L., Chase, M.A., Moritz, S.E., Sullivan, P.J. (1999). A conceptual model of coaching efficacy: Preliminary investigation and instrument development. Journal of Educational Psychology, 91,765-776.

[16] Feltz, D.L., Lirgg, C.D. (1998). Perceived team and player efficacy in hockey. Journal of Applied Psychology, 83,557564.

[17] Harackiewicz, J.M., Barron, K.E., Elliot, A.J. (1998). Rethinking achievement goals: When arethey adaptive for college students and why? Educational Psychologist, 33, 1-21.

[18] Hanin, Y. (1992). Social psychology and sport: Communication processes in top performance teams. Sport Science Review, I, 13-28.

[19] Hotuleva, M.S. (2009). The influence of psychotechnic exercises on a socially-psychological climate and unity of a sports team. Psychological Journal of International University of Nature, Society and Human "Dubna", http://www.psyanima.ru/ journal/2009/1/.

[20] Kavussanu, M., Roberts, G.C. (2001). Moral functioning in sport: An achievement goal perspective. Journal of Sport and Exercise Psychology, 23, 37-54.

[21] Kavussanu, M., Roberts, G.C., Ntoumanis, N. (2002). Contextual influences on moral functioning of college basketball players. The Sport Psychologist, 16, 347-367.

[22] Liden, R.C., Sparrowe, R., Wayne, S.J. (1997). Leader-member exchange theory: The past and potential for the future. Research in Personnel and Human Resource Management, I5, 47- 119.

[23] Lorentzen, S. (1994). A team is more than a line-up of players: An anecdote about handball, group observation and matrix. Group Analysis, 27(3): 257-263.

[24] Loy, J.W., McPherson, B.D., Kenyon, G. (1979). Sport and Social System. Massachusetts: Addison-Wesley Publishing Company.

[25] Lucic, Z., Viskic-Stalec, N. (1994). Sociometry structure of two generations of basketball players. Kinesiology, 26(1-2): 44-50.

[26] Marelic, T., Durkovic, T., Resetar, T. (2007). Interpersonal relationships cadet volleyball team before and after the sport event. Hrvatski športskomedicinski vjesnik, 22, 32- 39.

[27] Murray, N.P. (2006). The Differential Effect of Team Cohesion and Leadership Behavior in High School Sports. Individual Differences Research, 4(4), 216-225. 
[28] Newton, M., Duda, J. (1999). The interaction of motivational climate, dispositional goal orientations and perceived ability in predicting indices of motivation. International Journal of Sport Psychology, 30, 63-82.

[29] Nicholls, J.G. (1989). The competitive ethos and democratic education. Cambridge, MA: Harvard University Press.

[30] Ommundsen, Y., Roberts, G.C. (1999). Effects of motivational climate profiles on motivational indices in team sport. Scandinavian Journal of Science \& Medicine in Sports, 9, 389-397.

[31] Ommundsen, Y., Roberts, G.C., Lemyre, P.N., Treasure, D. (2003). Perceived motivational climate in male youth soccer; relations to social-moral functioning, sportspersonship and team norm perceptions. Psychology of Sport \& Exercise, 4, 397-413.

[32] Orlick, T. (1990). Winning through co-operation: Competitive insanity, cooperative alternatives. Washington DC: Acropolis Press.

[33] Prapavessis, H., Carron, A.V., Spink, K.S. (1996). Team building in sport. International Journal of Sport Psychology, 27,269-285.

[34] Roberts, G.C., Ommundsen, Y. (1996). Goal orientations and cognitive and affective correlates among team athletes. Scandinavian Journal of Sports Medicine, 6, 46-56.

[35] Rogulj, N., Nazor, M., Srhoj, V., Bozin, D. (2006). Differences between competitively efficient and less efficient junior handball players according to their personality traits. Kinesiology, 38(2), 158-163

[36] Serpa, S., Pataco, V., Santos, F. (1991). Leadership patterns in handball international competition. International Journal of Sport Psychology, 22(1), 78-89.

[37] Sahan, H., Tekin, M., Yildiz, M., Mutlu, O, Ulukan, M. (2012). A Study on the socialization levels of turkish female university students who do and who do not do sports. Energy Educ sci and Technol, Part B. Volume 4, Issue 2, April 2012.

[38] Shaffer, D.R. (2005). Social and Personality Development. Wadsworth: Cengage Learning.

[39] Spink, K.S. (1992). Group cohesion and starting status in successful and less successful elite volleyball teams. J Sports Sci., 10, 379-388.

[40] Simenc, Z. (1985). Analysis of micro-social structure of the water polo team of the method of multidimensional scaling] (Unpublished Doctoral dissertation). University of Zagreb.

[41] Snajder, G. (1984). Effect of urgent competitive situation at the micro social structure of a top volleyball teams. Kinesiology, 2, 199-205.

[42] Sullivan, P.A. (1993). Communication skills for interactive sports. The Sport Psychologist, 7, 79-91.

[43] Sullivan, P.J. (1995). The relationship between communication and cohesion in intercollegiate rugby players. Unpublished master's thesis, University of Windsor, Windsor, Ontario, Canada.

[44] Sullivan, P.J., Feltz, D.L. (2000). The relationship between intra-team conflict and cohesion within hockey teams. Small Group Research, 32,342-355.

[45] Treasure, D.C. (2001). Enhancing young people's motivation in youth sport: An achievement goal approach. In G.C. Roberts (Ed.), Advances in motivation in sport and exercise. Champaign, IL: Human Kinetics.

[46] White, S.A., Zellner, S.R. (1996). The relationship between goal orientation, beliefs about the causes of sport success, and trait anxiety among high school, intercollegiate and recreational sport participants. The Sport Psychologist, 10, 58-72.

[47] Widmeyer, W.N., Williams, J. (1991). Predicting cohesion in a coaching sport. Small Group Research, 22, 548-570.

[48] Williams, J., Widmeyer, W.N. (1991). The cohesion performance outcome relationship in a coaching sport. Journal of Sport and Exercise Psychology.

[49] Yaman, M., Yaman, T., Turkmen, M., (2003). Sporun universite adayi oglencinerilin ataklik ve pratik olma kişilik ozellikleri uzerine etkisi. Sakarya universitesi Egitim Fakultesi Dergisi, s, 16.

[50] Yilmaz, B. (2006). Effect of natural sports participation at social integration. Gazi University, Institute of Health Sciences, PhD thesis 2006, Ankara.

\section{Author' biography}

First \& corresponding author :

Mrs. Ioana Maria Curitianu.

Academic Qualification: PhD in Physical Education and Sports

Profession: Assistant PhD (Transilvania University - Faculty of Physical Education and Mountain Sports, Department of Physical Education and Special Motility)

Second Author: Mrs Elena Balint

Academic Qualification: PhD in Physical Education and Sports;

Profession: Professor (Transilvania University - Faculty of Physical Education and Mountain Sports, Department of Physical Education and Special Motility) 